\title{
Investigating Students' and Staff Members' Attitudes Toward the Efficiency of the Language Skills Modules Offered During the Foundation Year
}

\author{
Abdulmohsen A. Dashti ${ }^{1}$ \\ ${ }^{1}$ English department, College of Basic Education, PAAET, Kuwait \\ Correspondence: Abdulmohsen A. Dashti, English department, College of Basic Education, PAAET, Kuwait.
}

Received: March 26, 2019 Accepted: May 5, 2019 Online Published: May 7, 2019

doi: 10.5539/elt.v12n6p24 URL: https://doi.org/10.5539/elt.v12n6p24

\begin{abstract}
In the scope of teaching English as a foreign language, and more specifically teaching speaking, reading, and writing, this study investigated the attitudes English language teachers-to-be have towards the three language skills modules, namely, Conversation, Reading, and Basic writing, offered by the College of Basic Education (hereafter CBE) in Kuwait. It also investigated the concerns of staff members at the English department in CBE with regards to the matter. The study utilized two questionnaires, one distributed to the students' population, i.e., English major students (the sample received was (N 385), and the other one distributed to all staff members in the English department in CBE (N 27). In addition, 20 students were randomly selected and interviewed to verify the questionnaires' results. The data, then, were analysed both quantitatively and qualitatively. Percentages, means and standard deviations were calculated together with $t$ test and ANOVA. Results showed that even though most students and staff members showed positive attitudes towards most of the questionnaires' items, others were concerned about a few items.
\end{abstract}

Keywords: EFL, language skills, foundation year, attitudes

\section{Introduction}

The English program offered by the English department in CBE has been designed to meet the needs of primary school English classes. The program is a four-year program, of which the first year is the foundation year. During the foundation year, the students are offered three compulsory modules to improve their language skills prior to taking the core modules which revolve around linguistics, literature, and education. These compulsory modules are Conversation, Reading, and Writing. Despite the conclusions stated in previous studies, mainly, in the Kuwaiti setting, by (Dashti et al., 2014; Dashti \& Salama, 2013; Salama, 2004) that language skills of most of the students who have already finished the foundation year in the English department in CBE are absolutely unsatisfying, and hence, do not meet the real needs of the prospective EFL teachers, the department did not make any effort to further investigate the students' academic performance during the foundation year. Nor, there has been a study to investigate the students' and teachers' attitudes towards the efficiency of the three modules mentioned above. The sole study that was carried out was Dashti et al. (2014)' study which investigated the students' attitudes towards the efficiency of the conversation module only.

Learners' and teachers' attitudes are acknowledged as one of the most important factors that influence language learning (Fakeye, 2010). It is believed that besides openions and beliefs, attitudes towards learning have an obvious impact on learners' performance (Kara, 2009). Researchers have always focused on the importance of investigating Language learners' attitudes in EFL learning settings. (See, for example, Gardner, 1960; Gardner \& Lambert, 1972; Harmer, 2001; Otte, 2006; Soliman, 2013). Therefore, this research is an attempt to investigate English major students' attitudes towards the efficiency of the language skills modules offered to them during the foundation year.

\subsection{Importance of the Study}

There has been a continuous complaint by English language supervisors and English language head teachers at the Ministry of Education in Kuwait of the low proficiency of the graduates of the English major students in CBE. Moreover, the staff members in the English department who teach the core modules, that is, the modules offered during the second year on, also kept expressing their concerns regarding the students' poor skills in 
speaking, reading, and writing. For example, teachers who teach the linguistic modules (Introduction to linguistics, Phonetics and Phonology, Morphology and Syntax, Semantics) identified critical errors in students' pronumciation and their poor command of grammatical usage. Those who teach the literature modules pinpointed serious errors in students' writings. Teachers of core modules argued that it wasn't their job to concentrate on the students' language errors as they should only focus on the students' ability to understand the subject matter itself. Based on the above complaints, such language skills deficiency is deemed necessary for investigation. The degrading achievement of students in the English department in CBE compelled the researcher to investigate the reasons for such a problem.

\subsection{Theoretical Framework \& Literature Review}

There are four language skills deem important of EFL learners to achieve, two receptive skills, mainly, listening and reading, and two productive, namely, speaking and writing (Cooper, 2015; Zhang, 2013, Zhang, 2009). Research on the role of attitudes and motivation in EFL/ESL learning has aroused the interest of researchers all over the world (see for example, Al Samadani and Ibnian, (2015) in Saudi Srabia; Goktepe (2014) in Turkey; Tahaineh and Daana (2013) in Jordan; Bobkina and Fernandez (2012) in Madrid; Galloway (2011) in Japan; Chalak and Kassaian (2010) in Iran; Al Mamun et al. (2012) in Bangladesh; Yang (2012), Latifah et al. (2011) in Malay). The overall findings of the above studies showed that positive attitudes and motivation are related to success in second language learning (Gardner, 1985). Peregoy and Boyle (2001) proposed that class activities should integrate all listening skills, mainly reading, writing, speaking and listening. Ahmed (2015) proposed that all skills must have equal emphasis. Researchers believed a 'phonetics' module and a 'teaching pronunciation' module should be offered to the students in the foundation year (Dashti \& Salama, 2012; Doff, 2004). Besides, a module in spelling is of no less important as it acquaints the learners with the irregularities between the English phonemes and graphemes to remove or reduce the abundant spelling mistakes among Arab learners of English in particular (Shemish \& Waller, 2000; Harmer, 2005). Dashti et al. (2014) insisted on introducing a module in teaching grammar to freshman as they always show poor command of basic grammatical rules during their foundation year. Cheung (2011) emphasised the importance of listening comprehension in learning English as a foreign language (EFL) and argued that more emphasis should be given to listening comprehension. Kurniasih (2011) argued that most English teachers training colleges do not provide young learners with specialized training in how to meet the needs of primary school students. In investigating teaching English to young learners in Indonesia, she (ibid) stated that the status of English in the curriculum of primary schools in Indonesia is a local content, and thus the National Education Ministry does not provide English syllabus for primary schools. She (ibid) believed that the development of the four language skills should be made the focus of all learning activities. Punthamsen (2007) found out that most of the students do not want to learn English because they found the subject matter boring. They also claimed that the teaching methodology in the classroom was not interesting.

Researchers focused on the importance of using technology in EFL learning to help and improve language learning. Technology enables teachers to adapt classroom activities, thus enhancing the language learning process (Ahmadi, 2018; Haswani, 2014).

The worsening achievement of Arab students' language skills in the Arab world, in general, forced TEFL specialists to investigate the reasons for students' low achievement in Oral communication, reading, and writing skills in the target language (Kharma \& Hajjaj, 1989). In Kuwait, a number of studies investigated the same problem and pinpointed reasons such as poor linguistic standard of teachers, poor motivation, lack of confidence, the quality of teaching, and lack of interest in learning English (Al-Adwani, 2017; Al-Othman \& Shuqair, 2013; Kamil, 2011; Al-Muttawa, 1997). Saleh (2017) investigated the attitudes of 100 Libyan English EFL university students towards using authentic reading materials. The responses to his research questionnaire indicated that most of the students believed that exposing foreign language learners to authentic materials had a positive effect on developing their reading skills and on enhancing their awareness about target language culture. Yet, they highlighted the fact that such materials should be presented, and that teachers' and students' motivation and interest should be promoted in these materials. Alharbi (2015) investigated the causes of Saudi students' low proficiency in English communication and provided some recommendations to address these issues. Based on her results, she addressed the Ministry of Education and Higher Education to reform its language policies, where they should support the use of up-to-date approaches to teaching that focus on problem solving and critical thinking skills, put students in charge of their own learning, and consider converting some Saudi public schools into bilingual schools. Dashti et al. (2014) investigated English major students' attitudes towards the efficiency of the conversation module offered to them during their foundation year. The study indicated that most students 
felt that they had benefited from the conversation class in different areas; yet, many required a clearer outline of the course, and asked for more teaching hours for the conversation module.

Introducing short stories in the EFL class room positively contributes to the progress of the students' narrative writing (Adam, 2015). To test his hypothesis, Adam (ibid) attempted to improve Saudi university students writing narrative essays and promote story telling skills through presenting short stories to 30 students in the experimental group and none to 30 students in the control group. Relying on test retest method, the results showed that students in the experimental group better developed their narrative writing techniques than the control group.

\section{Methodology}

This paper aimed at investigating the attitudes of English major students and staff members at the department of English in CBE towards the efficiency of language skills modules, namely, Conversation, Reading, and Basic writing, offered to the students during the foundation year. Two tools have been utilised for data collection. First, two questionnaires have been designed, one distributed to all the English major students enrolled in the English department in the second semester 2017/2018 (N. 385), and one to all staff members currently teaching in the department (N. 27). The data were then quantitatively analysed using SPSS, where means, standard deviations, together with a t test and an ANOVA test have been produced. Both questionnaires were divided into three sections, each to investigate the students' and the staff members' attitudes towards each of the skills, i.e., Conversation, Reading, and Writing successively. The students' questionnaire (four-level Likert items: strongly disagree, disagree, agree, strongly disagree) contained 27 items where the staff members' questionnaire (four-level Likert items: strongly disagree, disagree, agree, strongly disagree) contained 36 items. The results of the students' questionnaire were analysed across age and year of study variables. Gender, here, was not a variable as the English major in the CBE is offered to female students only. The department of English is hoping to open the English major to male students next academic year. It is worthwhile mentioning that males and females are segregated in most government academic institutions in Kuwait, where there is a separate campus for males and another separate one for females. The results of the staff members' questionnaire, on the other hand, were analysed across gender, age, number of teaching experience in the department, and number of years teaching the three modules in the department. Second, 20 students were randomly selected to be interviewed to verify the questionnaire results. The interviews' questions were based on the questionnaire's results. The interviews were taken in a relaxed setting (the college cafeteria). A group of five students each time were asked by the researcher to meet him at the cafeteria and express freely their concerns regarding the three modules under discussion. The researcher has already told them that all conversations would be recorded, and the data would only be used for the purpose of the research.

\section{Research Questions}

This paper aimed at seeking answers to the following questions:

1) What are the students' attitudes towards the efficiency of the language skills modules, namely, Conversation, Reading, and Writing offered in the English department?

2) What are the staff members' attitudes towards the efficiency of the language skills modules, namely, Conversation, Reading, and Writing offered in the English department?

3) Is there any statistical significance between the students' attitudes towards the three modules and their age and year of study?

4) Is there any statistical significance between the staff members' attitudes towards the three modules and their gender, age, number of years teaching in the department, and number of years teaching the skills courses in the department?

\section{Results}

It is worth mentioning that before finalizing both questionnaires, the drafts were given to four staff members at the $\mathrm{CBE}$ and College of Education, Kuwait University, to seek their advice as to the validity of the questionnaires' items. The feedback was of great benefit. To test the reliability of the questionnaire, a Cronbach's Alpha test was carried out where it showed that both questionnaire items were reiliable (.845, students' questionnaire), (.847, staff members' questionnaire).

Question 1: What are the students' attitudes towards the efficiency of the language skills modules, namely, Conversation, Reading, and Writing offered in the English department?

The descriptive tests showed high means for most items except items 14 "Time allotted to teaching 'Writing' is 
adequate" (M 1.48), and 21 "Time allotted to teaching 'Reading' is adequate" (M 1.72).

Question 2: What are the staff members' attitudes towards the efficiency of the language skills modules, namely, Conversation, Basic Writing, and Reading, offered in the English department?

The descriptive tests showed high means for most items except items 16 "I prefer to have less teaching hours allotted to the Writing module" (M 1.94), 10 "the material presented to the students in the Conversation module is ineffective" (M 1.88), 22 "the material presented to the students in the writing module is ineffective" (M 1.88), 28 "'I prefer to have less teaching hours allotted to the Reading module" (M 1.83), and 34 "the material presented to the students in the Reading module is ineffective" (M 1.83).

Question 3: Is there any statistical significance between the students' attitudes towards the three modules and their age and year of study?

One-way ANOVA test was carried out. As to age significance, the results showed that items $3(>.000), 5(>.040)$, 13 (> .044), and 19 (> .002) were significant. As to item 3 (I prefer more teaching hours for the conversation module), the total mean was (M 2.72). The mean of the third age group (27+) was (M 3.22) which indicated that this age group aspired to have more teaching hours than the other two groups (18-20) and (23-27) respectively. As to item 5 (I prefer a language laboratory for the conversation module), the total mean was (M 3.34). The mean of the third age group (27+) was (M 3.60), which again designated that this same age group hoped to have a language laboratory for the conversation module, unlike the other two groups who didn't believe that a language laboratory was necessary. As to item 13 (I prefer more teaching hours for the writing module), the total mean was (M 2.10). The mean of the third age group (27+) was (M 2.44), which again indicated that this same age group wished to have more teaching hours than the other two groups. As to item 19 (I benefited a lot from the writing module), the total mean was (M 3.24). The mean of the third age group (27+) was (M 3.95), which again indicated that this same age group have benefited a lot from the writing module more than the other two groups did.

As to year significance, One-way ANOVA test showed that items 2, 5, 8, 14, 19, and 27 were significant at (>.026), (>.021), (>.029), (>.002), (>.016) and (>.043) respectively. As to item 2 (the number of teaching hours is enough), the total mean was (M 3.38). The mean of the first group (year 1) was (M 3.58) which indicated that this group believed that the number of teaching hours allotted to the conversation module was enough more than the other groups (year 2, 3, and 4) did. As to item 5 (I prefer a language laboratory for the conversation module), the total mean was (M 3.35). The mean of the fourth group (year 4) was (M 3.53) which indicated that this group believed that a language laboratory would be beneficial more than the other groups did. As to item 8 (one reason behind the students' low achievement in the conversation course is that different teachers teach different curricula), the total mean was (M 3.23). The mean of the fourth group (year 4) was (M 3.37) which indicated that this group agreed more on this issue than the other groups did. As to item 14 (the number of the teaching hours allotted to the writing module is enough), the total mean was (M 1.48). The mean of the fourth group (year 4) was (M 1.66) which indicated that this group hoped for more teaching hours more than the other groups did. As to item 19 (one reason behind the low efficiency of the students' reading skill is the lack of coordination among the staff members who teach the writing module), the total mean was (M 3.24). The mean of the first group (year 1) was (M 3.96) which indicated that this group agreed on that more than the other groups did. As to item 27 (the teaching hours for the reading module is enough), the total mean was (M 3.52). The mean of the fourth group (year 4) was (M 3.61) which indicated that this group agreed on this issue more than the other groups did. Question 4: Is there any statistical significance between the staff members' attitudes towards the three modules and their gender, age, number of years teaching in the department, and number of years teaching the skills courses in the department?

One-way ANOVA test was carried out. As to age and gender significance, the results showed no significance at all. As to the variable regarding the teaching experience in the department, the analysis showed that items 31 (one reason behind the low efficiency of the students' reading skill is the lack of coordination among the staff members who teach the reading module) was significant (>.003). The total mean for item 31 was (M 2.38). The means for the staff members who have been teaching for up to 5 years was (M 1.75), for those who have been teaching from 6-9 years was (M 1.33), and that of those who have been teaching for 10 years or more was (M 3.42. This clearly indicated that this final group believed that one reason behind the low efficiency of the students' reading skill was the lack of coordination among the staff members who teach the reading module. As to the final variable, namely, the number of years spent in teaching the three skills modules, the analysis showed that item 13 (the writing module satisfies the objectives set) and item 31 (one reason behind the low efficiency of the students' reading skills is the lack of coordination among the staff members who teach the reading module) 
showed significance at (>.004) and (>.024) respectively. The total mean for item 13 was (M 2.66). The means for the staff members who have been teaching the three skills modules for up to 5 years was (M 2.85), for those who have been teaching the three skills modules from 6-9 years was (M 3.14), and that of those who have been teaching the three skills modules for 10 years or more was (M 1.500). This clearly indicated that the first group believed that the writing module satisfied the objectives set more than the other groups did. On the other hand, the total mean for item 31 was (M 2.38). The means for the staff members who have been teaching the three skills modules for up to 5 years was (M 2.00), for those who have been teaching the three skills modules from 6-9 years was (M 2.00), and that of those who have been teaching the three skills modules for 10 years or more was (M 3.75). This, again, clearly indicated that this final group believed that one reason behind the low efficiency of the students' reading skill was the lack of coordination among the staff members.

\section{Discussion}

\subsection{Questionnaires}

Generally speaking, the results showed that the students and the staff members believed that introducing the three skills in the Foundation year is essential, a finding that goes along with those of Peregoy and Boyle (2001); and that class activities should integrate all listening skills, mainly reading, writing, speaking and listening as proposed by Peregoy and Boyle (2001). The findings also designated and that all skills must have equal emphasis as proposed by Ahmed (2015). Moreover, both students and staff members agreed on the importance of introducing a grammar module during the foundation year, a finding that corresponds with that of Dashti and Salama (2012) and Dashti et al. (2014).

\subsection{Students' Results}

The statistical results of the students' questionnaire above showed that the students claimed that all the three modules fulfilled their objectives. However, they opted to have more teaching hours to be allotted to writing and reading, a finding that contradicts with those of the staff members who claimed that the timing is quite enough. The students, in general, showed a desire to have several English native staff members teaching these three courses together with a sophisticated language laboratory as there is no language lab in the college, to improve their pronunciation. Such findings conform with those of Dashti and Salama (2012) and Doff (2004). The students didn't believe that the staff members' conversing in Kuwaiti Arabic with them outside the classroom was the main reason behind their low efficiency; they claimed that the subject matter introduced in the three modules was effective, and that all teachers followed a successful methodology. Again, this finding contradicts with that of the staff members who believed that the contents of all the three courses were inefficient. As to items 14 and 21, the students believed that they didn't see any reason for lessening the teaching hours for the writing module or the reading module.

As to age significance, the data showed that the third age group (+27) scored higher means than the other two age groups as to the items mentioned above. They, for example, prefered more teaching hours for the conversation module, hoped to have a language laboratory in the college, specifically, for the conversation module, and prefered more teaching hours for the writing module. This may be justified by mentioning that most of the students in this age group are on a study leave. They have left school for at least 8 years and now they are back to desk. Therefore, their English language standard is lower than the other age groups who joined the college right after finishing their high school. Moreover, some of them, as the interviews' investigations revealed (see below), are obliged by their employers to join the English department if they wanted to go on a study leave. So, majoring in English was not their choice. As to year significance, the statistical analysis above showed that items $2,5,8,14,19$, and 27 were significant. As to items 2 and 19, the results showed that the students in year 1 believed that the number of teaching hours allotted to the conversation course was while the other groups did not believe as much. This may be justified by mentioning that the Ministry of Education has recently started to allot more hours to speaking skills; hence, these students had had more opportunity to practice speaking in school prior to joining the college. As to the reading module (item 19), the students in year 1 believed that they benefited a lot from the reading module. This may be justified that the English department has recently decided that the textbook alone is not enough as a reading material. It introduced the idea of "pleasure reading" as a compulsory assignment. First year students are also asked to surf the Internet on weekly basis and get topics of their interest to read it in class followed by group discussions. As to items 5, 8, 14, and 27, the statistical analysis above showed that the results of the students in year 4 were more significant than those of the other groups. First, they aspired to have a language laboratory in the college. They wished to practice listening to native speakers of English to improve their listening and speaking skills before going out to the real field of teaching. During the meetings, which will be discussed later, the students who claimed the above preferences where all about to 
graduate. Most of them have either finished their practicum, where they are entitled to teach English in primary schools for a whole term or are now doing their practicum. They claimed that the actual teaching experience has given them a better vision than the others.

\subsection{Staff Members' Results}

As to the staff members' questionnaire, the analysis clearly showed that lack of coordination among the staff members was posing a problem. Out of the researcher's experience who have been teaching in the department since its establishment, staff members were reluctant to meet and coordinate even though during the first meeting in the beginning of every academic year, a coordinator is assigned to each module. Some of the reasons they provided was that they were busy with very tight schedules, their contradicting timetables as some teach in the morning and others in the afternoon, and that most of them believed that each staff member should feel free to follow his her own course plan and teaching methodology. It was crystal clear that those staff members who have been teaching for more than ten years did appreciate the idea of coordination as the English department's graduates' academic achievements proved to be below average. Moreover, this same group that has been teaching the basic skills for more than ten years were also unhappy with the way the writing module was presented, while the other groups were totally happy with it. Most teachers claimed that they do make use of technology inside their classrooms. They not only use technology in presenting their material, but also for taking class attendance and for correcting the students' exams. As for the importance of language labs, those teachers who teach the conversation module claimed that they always use their mobile phones in the classroom and present different applications and websites where the students are given a chance to listen to native speakers of English and carry out some listening and speaking tasks. Staff members unanimously agreed on the necessity to introduce a grammar module as all students show a very poor command of grammatical rules which badly affects their speaking and writing performance. One of their recommendations was to present a non-credit module for all new students before they begin their foundation year.

\subsection{Interviews}

As to the students' interviews, the most significant findings revoloved around the following points. The students claimed that most staff members did not make use of technology as other staff members in other departments did. They would love to do more of their work through programs like Edmodo and other educational tools. They would like their teachers to direct them to make good use of current websites to brush up their spoken, listening, reading, and writing skills. These views quite fitted with those of Ahmadi (2018), and Heswani (2014). The students expressed a desire to have a grammar module in their foundation year as they felt they were not very well equipped with grammatical accuracy prior to joining the college, a fact, they claimed, was behind their poor achievements in the three language skills. This finding goes along with those of Dashti et al (2014). However, they didn't believe that their teachers' performance and command of English were poor, a claim which contradicts with the conclusion drawn by Kamil (2011) and AlMuttawa (1997). They claimed that their teachers were highly qualified, albeit they kept complaining of the frequent class cancelation by teachers. They claimed that they were in favor of the idea of recruiting staff members whose native language is English, not because their teachers are not qualified, but because other similar institutions do have English language speakers in the English department. Some believed that it might be a good idea for English native staff members to teach the conversation course, but not reading or writing. One other point was that many interviewees complained of old-fashioned curricula. They claimed that some staff members relied on textbooks dated to 1970's. It is worthwhile mentioning that most students assume that the term "curricula" refers to the textbook only, and many staff members, unfortuanely, stick only to the textbook. This way of thinking needs to be revolutionized. Staff members must be encouraged to ask their students to consult other available sources besides the textbook. Finally, although the statistical results showed no complaint of the teaching hours allotted to the conversation module, the interviewees asked for more teaching hours for the conversation module, which corresponds with the conclusion drawn by Dashti et al (2014). One point to mention here is that since the establishment of the department, five hours were allotted for the teaching of the three modules, namely, conversation, reading, and writing. Unfortunately, a decision was taken recently to lessen the number to three hours instead of five. This was done for the benefit of the teachers and not the students. Some teachers believed that most of the teachers who used to teach the three-language skills module for five hours were not actually teaching the whole five hours; they used to skip two hours with no one asking them why. This is an ethical issue, and its discussion is beyond the scope of this study. One of the complaints by the students is that the teachers did not interact with them in English outside the lecture hall. Once, a big sign that reads "English- speaking Zone" was posted in the department's corridor; unfortunately, the idea wasn't welcomed by the staff members.

When approaching the staff members to investigate their attitudes, the teachers with less experience claimed that 
technology has changed the way they teach which they find it advantageous. However, the group with more experience of teaching the language skills course claim that those two groups relying on technology per se in not quite enough.

\section{Conclusion}

This paper was meant to investigate students' and staff members' attitudes toward the efficiency of the language skills modules offered during the foundation year in the English department, College of Basic Education. Results showed that, both students and staff members were satisfied with the program offered as far as the efficacy of the language skills modules, yet they expressed some concerns regarding a few issues, with opposing views in some respects. The students mainly focused on the need of recruiting native speakers of English and the importance of launching sophisticated language labs in the college, the desire to allot more hours to the teaching of writing, and the urge of using social media apps in and outside the classroom to facilitate the teaching/learning process. Staff members, on the other hand, claimed that three hours are pretty enough for each module. However, they claimed that lack of coordination between the teachers sometimes posed a problem. Finally, both students and staff members believed that the syllable's contents for all the courses may best be revised. In this respect, the researcher recommends that the college administration should listen to the students regarding providing different educational facilities. The researcher would suggest, here, that thinking of launching a student hob is a necessity to act as both recreational and educational center. The English department should also take a step to revise all language skills syllables to meet better standards.

\section{Acknowledgements}

This research paper is funded by The Public Authority for Applied Education and Training.

I would like to thank The Public Authority for Applied Education and Training for kindly supporting and funding this research paper, Research No. (BE-17-16), entitled 'Investigating students' and staff members' attitudes toward the efficiency of the language skill courses offered during the foundation year". Many thanks to all the students and staff members in the English department, College of Basic Education, who participated in this study. My thanks are also extended to my colleagues in the department who provided me with their feedback during the research process.

\section{References}

Adam, A. A. S. (2015). Developing EFL Learners' Narrative Writing Through using short stories: The case of AL-BAHA University students. European Journal of English Language and Literature Studies, 3(4), 1-8.

Ahmadi, M. R. (2018). The Use of Technology in Language Learning: A literature review. International Journal of Research in English Education, 3(2). https://doi.org/10.29252/ijree.3.2.115

Ahmed, S. H. (2015). Attitudes towards English Language Learning among EFL Learners at UMSKAL. Journal of Education and Practice, 6(18).

Al-Adwani, A. M. (2017). Language learning strategy preference among EFL students in the college of Basic education in Kuwait. British Journal of Education, 5(12), 43-59.

Alharbi, A. E. (2015). Improving Students' English Speaking Proficiency in Saudi Public Schools. International Journal of Instruction January, 8(1). https://doi.org/10.12973/iji.2015.818a

Al Mamun, S. A., Rahman, A. R. M. M., Rahman, A. R. M. R., \& Hossain, M. A. (2012). Students' Attitudes towards English: The Case of Life Science School of Khulna University. International Review of Social Sciences and Humanities, 3(1), 200-209.

Al-Mutawa, N. A. (1997). Evaluation of EFL Primary School Teachers' Competencies in Kuwait. Evaluation \& Research in Education, 11(1). https://doi.org/10.1080/09500799708666915

Al-Othman, F. H. M., \& Shuqair, K. M. (2013). Effectiveness of the Remedial Courses on Improving EFL/ESL Students' Performance at University Level. International Journal of Higher Education, 2(3). https://doi.org/ 10.5430/ijhe.v2n3p132

Al Samadani, H. A., \& Ibnian, S. S. (2015). The Relationship between Saudi EFL Students' Attitudes towards Learning English and their Academic Achievement. International Journal of Education and Social Science, 2(1), 92-102.

Bobkina, J., \& Fernandez de, M .C. D. (2012). Motivation and Attitudes towards Learning English: A Study of Engineering Undergraduates at the Technical University of Madrid. ICERI2012 Proceedings, 4492-4501.

Chalak, A., \& Kassaian, Z. (2010). Motivation and Attitudes of Iranian Undergraduate EFL Students towards 
Learning English. GEMA Online Journal of Language Studies, 37-56.

Cooper, A. (2015). Facilitating the Development of Basic Language Skills in the English as a Foreign Language Classroom.

Dashti, A., Akbar, R., \& Taqi, H. (2014). Investigating english major students' attitudes towards the efficiency of the "conversation" course. International Journal of English Language Teaching, 2(4), 56-66.

Dashti, A., \& Salama, G. (2013). Evaluating the EFL preparatory program at the department of English, college of education, PAAET. Annals of the Faculty of Arts. Ain Shams University, 41.

Doff, A. (2004). Teach English - A training course for teachers. Cambridge University Press.

Faykeye, D. (2010). Students' Personal Variables asCorrelates of Academic Achievementin English as aSecond Language in Nigeria. Journal of Social Sciences, 22(3), 205-211.

Galloway, N. (2011). An investigation of Japanese university students' attitudes towards English (Unpublished Ph.D. dissertation, University of Southampton, UK).

Gardner, R. (1960). Motivation and second language acquisition: The socio-educational model. City: Publisher.

Gardner, R., \& Lambert, W. (1972). Attitudes and motivation in second language learning. Rowley, MA: Newburn House.

Goktepe, F. T. (2014). Attitudes and Motivation of Turkish Undergraduate EFL: Students towards Learning English Language. Studies in English Language Teaching, 2, 314-332. https://doi.org/10.22158/ selt.v2n3p314

Harmer, J. (2001). The practice of English language teaching (3rd ed.). London: Longman.

Haswani, F. (2014). The Role of Technology in EFL Classroom. Indonesian Journal of English Education, 1(2). https://doi.org/10.15408/ijee.v1i2.1303

Kamil, I. (2011). Perceptions of Kuwaiti EFL Student-Teachers towards EFL Writing and Methods of Teaching and Learning EFL writing (Unpublished PhD thesis, University of Exter).

Kara, A. (2009). The Effect of a "Learning Theories" Unit on Students' Attituses towards Learning. Australian Journal of Teacher Education, 34(3), 100-113.

Kharma, N. N., \& Hajjaj, A. H. Use of the Mother Tongue in the ESL Classroom. IRAL, 27(3), 223-235.

Latifah, A. L., Mansor, F., Ramli, B., Wardah, M., \& Ng Man, S. (2011). The Role of Motivation, Attitude, Anxiety, and Instrumental Orientation in Influencing Learners' Performance in English as Second Language in OUM.

Peregoy, S. F., \& Boyle, O. F. (2001). Reading, writing, and learning in ESL: A resource book for K-12 teachers. New York: Addison Wesley Longman, Inc.

Punthumasen, P. (2007). International Program for Teacher Education: An Approach to Tackling Problems of English Education in Thailand. The 11th UNESCO-APEID international conference.

Otte, J. (2006). Real language to real people: A descriptive and exploratory case study of the outcomes of aural authentic texts on the listening comprehension of adult ESL students enrolled in an advanced ESL listening course. Dissertation Abstracts International, 67(4), 1246B.

Salama, G. (2004). A Proposed Revision for English Language Teacher Preparation in Egyptian National Universities. Egyp Tesol Journal.

Saleh, S. E. (2017). Some Libyan EFL University Students' Attitudes towards Using Authentic Materials for Reading Classes. Theory and Practice of Second Language Acquisition, 3(1), 61-75.

Shemesh, R., \& Sheila, W. (2000). Teaching English Spelling. Cambridge University Press.

Soliman, S. (2013). Libyan teachers' attitudes and believes regarding the use of EFL authentic materials within reading lessons at universities levels in Libya. International Journal of Learning \& Development, 3(5), 121-129. https://doi.org/10.5296/ijld.v3i5.4484

Tahaineh, Y., \& Daana, H. (2013) Jordanian Undergraduates' Motivations and Attitudes towards Learning English in EFL Context. International Review of Social Sciences and Humanities, 4(2), 159-180.

Zhang, L. J. (2013). Second language writing as and for second language learning. Journal of Second Language Writing, 22, 446-447. https://doi.org/10.1016/j.jslw.2013.08.010 
Zhang, S. (2009). The role of input, interaction, and output in the development of oral fluency. English Language Teaching, 2(4), 91-100. https://doi.org/10.5539/elt.v2n4p91

\section{Copyrights}

Copyright for this article is retained by the author(s), with first publication rights granted to the journal.

This is an open-access article distributed under the terms and conditions of the Creative Commons Attribution license (http://creativecommons.org/licenses/by/4.0/). 